\title{
31. A MÖSSBAUER STUDY OF SAPONITE IN LAYER 2 BASALT, DEEP SEA DRILLING PROJECT LEG 691
}

\author{
A. J. Andrews, Ontario Geological Survey, 77 Grenville Street, Toronto, Ontario, M5S 1B3, Canada \\ W. A. Dollase, University of California, Los Angeles, Earth and Space Sciences Department, Los Angeles, California \\ and \\ M. E. Fleet, University of Western Ontario, Department of Geology, London, Ontario, N6A 5B7, Canada
}

\begin{abstract}
Mössbauer analyses were conducted on a sample of saponite selected from DSDP Leg 69 basalt core. The sample was initially placed within a nitrogen-purged container on-board Glomar Challenger approximately three hours after recovery, where it remained until analysis. The Mössbauer data revealed an original, in situ $\mathrm{Fe}_{2} \mathrm{O}_{3} / \mathrm{FeO}$ ratio of 0.46 , with both $\mathrm{Fe}^{2+}$ and $\mathrm{Fe}^{3+}$ in octahedral coordination. With controlled exposure to air under ambient laboratory storage conditions, the proportion of $\mathrm{Fe}^{3+}$ increased from an original $30 \%$ to $51 \%$ over a period of about 11.5 months. The $\mathrm{Fe}^{3+}$ thus produced remained in octahedral coordination, and no observable changes occurred in the physical appearance of the sample.
\end{abstract}

\section{INTRODUCTION}

In this report we present results of a preliminary study of the in situ, original oxidation state and structural location of iron in saponite, a secondary mineral formed during low-temperature alteration of basalt recovered during DSDP Leg 69.

Deep drilling of oceanic crust over the past decade has revealed that basalt diagenesis-a low-temperature, sub-zeolite alteration effect resulting from interaction of basalt with percolating sea water-is widespread and persistent in Layer 2, and most likely extends to depths on the order of a kilometer or more. A number of studies, including those of Bass (1976), Andrews (1977, 1979, 1980), Seyfried et al. (1978), and Böhlke et al. (1980) have revealed that phyllosilicates in the form of saponite and celadonite represent the most abundant and widespread components of this low-grade alteration; however, there is still much to learn concerning their mineral chemistry and conditions of formation. For example, because the bulk compositions of both saponite and celadonite include significant quantities of iron (Andrews, 1980), the fugacity of oxygen $\left(f_{\mathrm{O}_{2}}\right)$ must play an important role in controlling their stability and occurrence. A corollary is that knowledge of the oxidation state of iron in these secondary phases will provide a means for estimating the relative $f_{\mathrm{O}_{2}}$ of the alteration environment in which they form.

While a significant amount of data concerning the mineral chemistry and stability range of celadonite already exists (for example, Wise and Eugster, 1964; Velde, 1972), information with regard to saponite is virtually nonexistent. There are only a few published analyses of saponite recovered from deep-ocean-floor basalts which include data on the oxidation state of iron (determined

\footnotetext{
${ }^{1}$ Cann, J. R., Langseth, M. G., Honnorez, J., Von Herzen, R. P., White, S. M., et al.,
} Init. Repts. DSDP, 69: Washington (U.S. Govt. Printing Office). by $\mathrm{XRF}$ and wet chemical techniques). These are usually characterized by high $\mathrm{Fe}^{3+}$ contents, with $\mathrm{Fe}^{3+} / \mathrm{Fe}^{2+}$ ratios significantly greater than unity (for example, see Banks, 1972). However, there is a strong probability that these high $\mathrm{Fe}^{3+}$ contents are not original, but result from oxidation which occurs after sample recovery (Kohyama et al., 1973). In order to properly investigate the original oxidation state of iron in clay minerals, specimens must be stored in an oxygen-free atmosphere immediately following sample recovery, until analysis. To our knowledge, no precautions of this nature have ever been implemented with respect to examination of clay minerals in deep-ocean-floor basalts. In addition, the classical techniques employed for determining iron in minerals do not distinguish between $\mathrm{Fe}^{3+}$ intrinsic within the saponite structure and that external to the structure; for example, $\mathrm{Fe}^{3+}$ adsorbed on surfaces and/or occurring as finely intermixed, amorphous iron oxides (hydroxides).

In this context, our purpose in this preliminary investigation is to provide information concerning (1) the original proportions of $\mathrm{Fe}^{2+}$ and $\mathrm{Fe}^{3+}$ in deep-oceanfloor saponites, representative of the environment in which they form; (2) the nature of $\mathrm{Fe}^{2+}$ and $\mathrm{Fe}^{3+}$ incorporation within the saponite structure; and (3) the susceptibility of saponite to oxidation after recovery.

This report serves as a preface to more-detailed experimental studies to follow, concerning the Eh stability range of saponite and its relationship to more-oxidized secondary phases such as nontronite and celadonite.

\section{METHODS}

Nine very excellent occurrences of smectite were sampled from basalts of Holes $501\left(1^{\circ} 13.63^{\prime} \mathrm{N}, 83^{\circ} 44.06^{\prime} \mathrm{W}\right)$ and $504 \mathrm{~B}\left(1^{\circ} 13.63^{\prime} \mathrm{N}\right.$, $83^{\circ} 43.81^{\prime} \mathrm{W}$ ) recovered during DSDP Legs 68 and 69 . Approximately 3 hours elapsed between their being removed from the sub-sea-floor environment by drilling and their being placed in a nitrogen-purged container aboard Glomar Challenger, where they remained until analysis. The samples, which are briefly described in Table 1, consist of altered basalt containing smectite on surfaces, as a matrix to hyalo- 
Table 1. Sample descriptions and X-ray results.

\begin{tabular}{|c|c|c|c|}
\hline \multirow{2}{*}{$\begin{array}{c}\text { Sample } \\
\text { (interval in } \mathrm{cm} \text { ) }\end{array}$} & \multirow[b]{2}{*}{ Description } & \multicolumn{2}{|c|}{ XRD Results ( $(\AA)$} \\
\hline & & 100 & 060 \\
\hline $501-11-2,132-134$ & $\begin{array}{l}\text { Basalt fragment with phyllo- } \\
\text { silicate-coated surfaces }\end{array}$ & $13.4-17.0 \mathrm{~s}$ & $1.535 \mathrm{~m}$ \\
\hline $501-11-3,102-106$ & $\begin{array}{l}\text { Basalt fragment with phyllo- } \\
\text { silicate-coated surfaces } \\
\text { and veins }\end{array}$ & - & - \\
\hline $501-14-2,20-23$ & $\begin{array}{l}\text { Basalt fragment with } \\
\text { phyllosilicate-coated } \\
\text { surfaces }\end{array}$ & - & - \\
\hline $501-19-1,140-142$ & $\begin{array}{l}\text { Hyaloclastite; open frame- } \\
\text { work of altered glass and } \\
\text { basalt fragments in a } \\
\text { matrix of phyllosilicate }\end{array}$ & $14.8-17.0 \mathrm{vs}$ & $1.535 \mathrm{~m}$ \\
\hline 504B-5-1, 124-127 & $\begin{array}{l}\text { Basalt fragments with thick } \\
\text { surface coating of dark- } \\
\text { green and olive-green } \\
\text { phyllosilicate }\end{array}$ & $\begin{array}{l}14.8-17.0 \mathrm{vs} \\
10.2 \mathrm{vw}\end{array}$ & $1.533 \mathrm{~m}$ \\
\hline 504B-6-1, 93-95 & $\begin{array}{l}\text { Basalt fragment containing } \\
0.5-\mathrm{cm} \text {-wide phyllosili- } \\
\text { cate vein }\end{array}$ & $15.2-17.0$ vs & $1.535 \mathrm{~m}$ \\
\hline $504 \mathrm{~B}-7-1,26-27$ & $\begin{array}{l}\text { Basalt fragment containing } \\
\text { thin partings of phyllosilicate }\end{array}$ & - & - \\
\hline $504 \mathrm{~B}-15-1,79-81$ & $\begin{array}{l}\text { Basalt fragment containing } \\
\text { phyllosilicate in large vugs } \\
\text { and veins }\end{array}$ & $12.6-17.0$ vs & $1.526 \mathrm{~m}$ \\
\hline $504 \mathrm{~B}-24-2,23-24$ & $\begin{array}{l}\text { Hyaloclastite with altered basalt } \\
\text { fragments in a matrix of } \\
\text { phyllosilicate }\end{array}$ & - & - \\
\hline
\end{tabular}

Note: $13.4-17.0$ means 13.4 expands to 17.0 with glycolation; $\mathrm{s}=$ strong, $\mathrm{vs}=$ very strong, $\mathrm{vw}=$ very weak, $\mathrm{m}=$ moderate; $-=$ not analyzed.

clastite breccia, and in veins up to $0.8 \mathrm{~cm}$ in width. X-ray-diffraction patterns of all but one of the five samples selected for analysis indicate a composition of monomineralic saponite (Table 1). Sample 504B-5-1, $124-127 \mathrm{~cm}$ showed a small $10 \AA$ peak adjacent to the 001 saponite reflection, suggesting the presence of a finely intermixed mica component, probably celadonite.

Saponite occurring in a 0.5 -cm-wide vein in Sample 504B-15-1, $79-81 \mathrm{~cm}$ was selected for Mössbauer examination. In hand specimen, the saponite appears as a homogeneous, fine-grained, olive-green, compact mass, occupying the entire vein. In thin-section, it appears as small, radiating, fibrous needles ( $0.05 \mathrm{~mm}$ in length) arranged as an intact framework of rosette clusters. Careful X-ray and microscopic examination confirmed, within the limits of detection, the presence of pure, monomineralic saponite.

A small section of the vein was cut intact from the specimen, mounted in epoxy, and carefully polished. The composition of the saponite then was examined by electron-microprobe analysis (MAC 400 microprobe with Krisel automation), using a $15-\mathrm{kV}$ excitation voltage, 0.020 to $0.025-\mu \mathrm{A}$ beam current, and 20 -sec counting times. The analyses were calibrated against the following standard materials: $\mathrm{Si}, \mathrm{Mg}$, Fe: orthopyroxene; $\mathrm{Al}, \mathrm{Ti}$ : kaersutite; $\mathrm{Ca}$ : diopside; $\mathrm{Cr}$ : chromite; Mn: rhodonite; Na: albite; K: orthoclase.

Room-temperature Mössbauer analyses were conducted on four separate 150 to 200 -mg aliquots of saponite separated from the vein. One analysis was conducted on saponite not exposed to air (that is, saponite which had remained in nitrogen atmosphere since recovery), and three were made on aliquots which had been exposed to laboratory air for successively longer periods of time; 100,1200 , and 8350 hours (about 4 days, 50 days, and 11.5 months, respectively). Each saponite aliquot was physically disaggregated from the compact vein mass under glovebox conditions (nitrogen atmosphere). The latter three were then left to oxidize for the indicated periods. No grinding was conducted at this stage. Prior to Mössbauer analysis, each aliquot was gently comminuted, and the powder was mixed with warm Vaseline to achieve a random orientation. Aliquots 1, 2, and 3 (Table 2) were analyzed at the University of California, Los Angeles, and aliquot 4 was analyzed at the University of Western Ontario.

\section{RESULTS}

\section{Electron-Microprobe Analyses}

Six electron-microprobe analyses were conducted at various locations within the saponite vein section (Table
Table 2. Mössbauer parameters and $\mathrm{Fe}^{3+}$ proportion in air-oxidized saponite.

\begin{tabular}{|c|c|c|c|c|c|c|}
\hline \multirow[b]{2}{*}{ Aliquot } & \multirow{2}{*}{$\begin{array}{c}\text { Air } \\
\text { Exposure } \\
(\mathrm{hr})\end{array}$} & \multicolumn{3}{|c|}{ Parameters } & \multirow[b]{2}{*}{ Assignment } & \multirow{2}{*}{$\begin{array}{c}\text { Proportion } \\
\text { of } \mathrm{Fe}^{3+} \\
(\%)\end{array}$} \\
\hline & & I.S. & Q.S. & $\mathrm{T}$ & & \\
\hline \multirow[t]{2}{*}{1} & 0 & 1.11 & 2.73 & 0.32 & $\mathrm{Fe}^{2+}, \mathrm{M}$ & $30 \pm 2$ \\
\hline & & 0.44 & 1.03 & 0.60 & $\mathrm{Fe}^{3+}, \mathrm{M}$ & \\
\hline \multirow[t]{2}{*}{2} & 100 & 1.11 & 2.71 & 0.36 & $\mathrm{Fe}^{2+}, \mathrm{M}$ & $35 \pm 1$ \\
\hline & & 0.42 & 1.03 & 0.57 & $\mathrm{Fe}^{3+}, \mathrm{M}$ & \\
\hline \multirow[t]{2}{*}{3} & 1200 & 1.13 & 2.72 & 0.35 & $\mathrm{Fe}^{2+}, \mathrm{M}$ & $39 \pm 1$ \\
\hline & & 0.44 & 1.10 & 0.56 & $\mathrm{Fe}^{3+}, \mathrm{M}$ & \\
\hline \multirow[t]{3}{*}{4} & 8350 & 1.07 & 2.71 & 0.32 & $\mathrm{Fe}^{2+}, \mathrm{M}$ & $51 \pm 1$ \\
\hline & & 0.41 & 1.22 & 0.45 & $\mathrm{Fe}^{3+}, \mathrm{M}(1)$ & \\
\hline & & 0.34 & 0.85 & 0.45 & $\mathrm{Fe}^{3+}, \mathrm{M}(2)$ & \\
\hline
\end{tabular}

Notes: I.S. = isomer shift; Q.S. quadrupole splitting; $\mathrm{T}=$ peak width at half height; $\mathrm{M}, \mathrm{M}(1), \mathrm{M}(2)=$ octahedral sites.

3). In general, the oxide abundances are fairly typical of saponites recovered from Layer 2 basalts (for example, see Andrews 1977, 1980), and on the whole are relatively constant from one location to the other, suggesting a rather homogeneous composition throughout the vein. Cation abundances (Table 4, column 1) were calculated from the average composition on the basis of 20 oxygens and 4 hydroxyls (44 cationic charges per formula unit), and assuming total iron as $\mathrm{FeO}$. Ideally, the trioctahedral saponite structure is characterized by an octahedral, cationic sum of 6 , and a layer charge deficiency originating entirely from the substitution of $\mathrm{Al}^{3+}$ for $\mathrm{Si}^{4+}$ in tetrahedral layers. Note that the average sample (Table 4, Column 1) is characterized by a slightly low octahedral sum, and an apparent negative octahedral layer charge compared to this ideal structure.

\section{Mössbauer Analysis}

Room-temperature Mössbauer parameters for the four analyzed aliquots of saponite are reported in Table 2 , and the spectrum for aliquot 4 (longest air exposure) is reproduced in Figure 1. All spectra were fitted to pure Lorentzian line shapes. The good agreement obtained with symmetrical doublets demonstrates the lack of preferred orientation in the sample preparation, an optimum condition for Mössbauer analysis of clay minerals. Site assignments were made after the procedure of Rozenson and Heller-Kallai $(1977 ; 1978)$ for dioctahedral smectites. The spectrum for aliquot 4 (Fig. 1) has

Table 3. Electron-microprobe analyses of saponite in Sample 504B-15-1, 79-81 cm.

\begin{tabular}{lrrrrrr}
\hline & \multicolumn{6}{c}{ Analysis } \\
Component & \multicolumn{1}{c}{1} & \multicolumn{1}{c}{2} & \multicolumn{1}{c}{3} & \multicolumn{1}{c}{4} & \multicolumn{1}{c}{5} & \multicolumn{1}{c}{6} \\
\hline $\mathrm{SiO}_{2}$ & 46.39 & 48.39 & 47.26 & 47.64 & 46.28 & 47.93 \\
$\mathrm{Al}_{2} \mathrm{O}_{3}$ & 6.29 & 4.68 & 4.41 & 5.46 & 5.82 & 4.61 \\
$\mathrm{FeO}^{*}$ & 9.89 & 8.59 & 8.90 & 9.71 & 9.62 & 8.53 \\
$\mathrm{MgO}$ & 20.65 & 21.66 & 21.39 & 20.62 & 20.39 & 21.06 \\
$\mathrm{CaO}$ & 1.54 & 1.35 & 0.45 & 1.48 & 1.00 & 1.14 \\
$\mathrm{Na}_{2} \mathrm{O}$ & 2.33 & 1.34 & 1.99 & 2.17 & 2.32 & 2.04 \\
$\mathrm{~K}_{2} \mathrm{O}$ & 0.00 & 0.01 & 0.03 & 0.01 & 0.03 & 0.02 \\
Total & 87.09 & 86.02 & 84.43 & 87.09 & 85.46 & 85.33 \\
\hline
\end{tabular}

Note: Total iron calculated as $\mathrm{FeO}$. 
Table 4. Cation abundances of saponite calculated from the average composition in Table 3.

\begin{tabular}{lcc}
\hline & \multicolumn{2}{c}{ Analysis } \\
Cation & 1 & 2 \\
\hline $\mathrm{Si}$ & 7.12 & 7.06 \\
$\mathrm{Al}$ & 0.88 & 0.91 \\
$(\mathrm{IV})$ & 8.00 & 7.97 \\
$\mathrm{Fe}^{3+}$ & - & 0.34 \\
$\mathrm{Fe}^{2+}$ & 1.16 & 0.81 \\
$\mathrm{Mg}$ & 4.70 & 4.66 \\
$\mathrm{Al}$ & 0.04 & 0 \\
$(\mathrm{VI})$ & 5.90 & 5.81 \\
$\mathrm{Ca}$ & 0.23 & 0.22 \\
$\mathrm{Na}$ & 0.60 & 0.59 \\
$\mathrm{~K}$ & 0 & 0 \\
$(\mathrm{X})$ & 0.83 & 0.81 \\
$\Sigma_{\text {IV }}$ & -0.88 & -1.03 \\
$\Sigma_{\text {VI }}$ & -0.16 & -0.04 \\
Total & -1.04 & -1.07 \\
$\Sigma_{\mathrm{X}}$ & +1.06 & +1.03 \\
\hline
\end{tabular}

Notes: $\Sigma_{I V}=$ tetrahedral layer charge; $\Sigma_{\mathrm{VI}}=$ oc tahedral layer charge; $\Sigma_{\mathbf{X}}=$ interlayer charge; Column 1: total iron as $\mathrm{FeO}$; Column 2: $\mathrm{FeO}=$ 6.54 wt. $\%$ and $\mathrm{Fe}_{2} \mathrm{O}_{3}=$ $3.04 \mathrm{wt} . \%$, as indicated from Mössbauer analysis 1 (Table 2).

been resolved into one doublet corresponding to octahedrally coordinated $\mathrm{Fe}^{2+}$ in $\mathrm{M}(1)$ and/or $\mathrm{M}(2)$ sites, and two doublets corresponding to octahedrally coordinated $\mathrm{Fe}^{3+}$ in $\mathrm{M}(1)$ (trans configuration in respect to $\mathrm{OH}^{-}$groups, peaks 2 and 5) and $\mathrm{M}(2)$ (cis configuration, peaks 3 and 4) sites. The resolution between the $\mathrm{M}(1)$ and $\mathrm{M}(2) \mathrm{Fe}^{3+}$ sites is lost in aliquots 1, 2, and 3, which have a smaller proportion of $\mathrm{Fe}^{3+}$, and only a single $\mathrm{Fe}^{3+}$ doublet with broadened peaks has been reported (Table 2). Following Rozenson and Heller-Kallai (1977), proportions of $\mathrm{Fe}^{3+}$ (Table 2) were calculated directly from the relative peak areas of the $\mathrm{Fe}^{2+}$ and $\mathrm{Fe}^{3+}$ doublets.

The Mössbauer data for the aliquot of saponite not exposed to air indicate an original $\mathrm{Fe}_{2} \mathrm{O}_{3} / \mathrm{FeO}$ ratio of 0.46 (that is, a proportion of about $30 \% \mathrm{Fe}^{3+}$ ), both species being located entirely within octahedral sites. Exposure of the saponite aliquots to air caused gradual oxidation, such that after a period of $8350 \mathrm{hr}(11.5$ months) the $\mathrm{Fe}_{2} \mathrm{O}_{3} / \mathrm{FeO}$ ratio had increased to a value of 1.2 (a proportion of about $51 \% \mathrm{Fe}^{3+}$ ). The curve in Figure 2 suggests that an equilibrium had been closely approached at $8350 \mathrm{hr}$ of exposure, and that the proportion of $\mathrm{Fe}^{3+}$ probably would not have increased beyond a value of about $60 \%$. The Mössbauer spectra of the exposed aliquots indicate that all $\mathrm{Fe}^{3+}$ produced during oxidation remained in octahedral sites. It is perhaps important to note that this oxidation caused no observable change in the physical appearance of the samples.

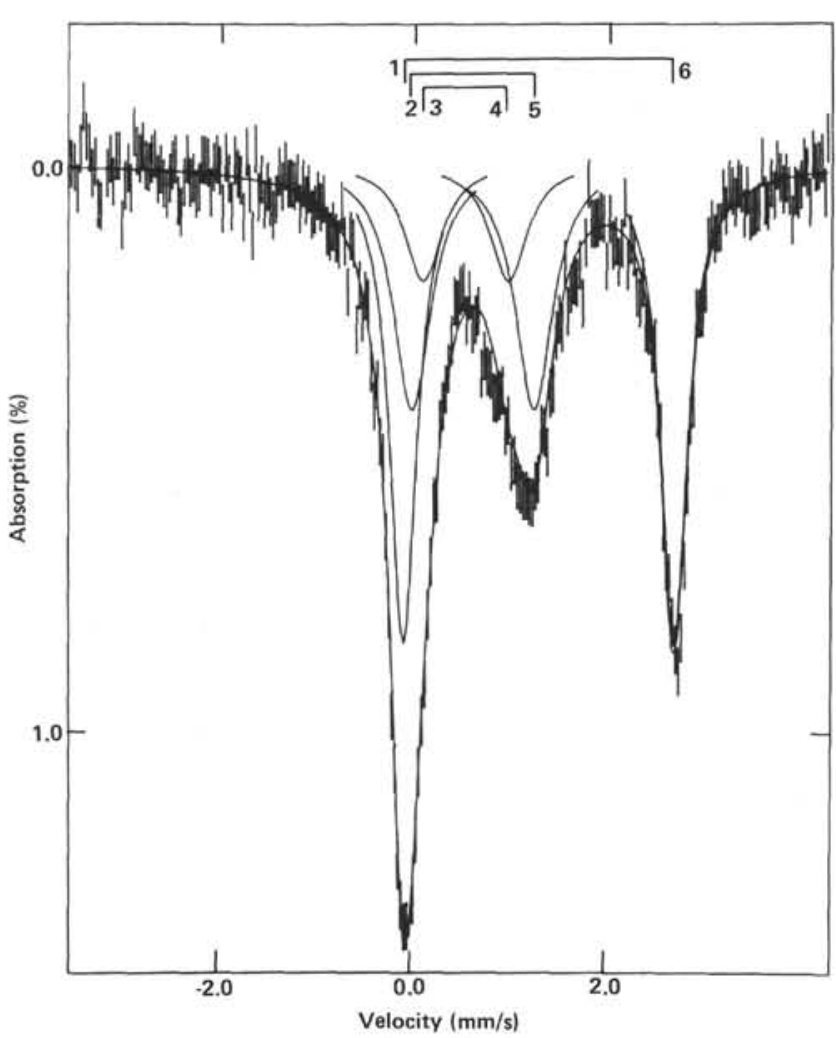

Figure 1. Mössbauer spectrum of air-oxidized saponite (aliquot 4 , 8350-hr air exposure). Peaks 1 and $6=\mathrm{Fe}^{2+} \mathrm{M}$, site doublet; peaks 2 and $5=\mathrm{Fe}^{3+}, \mathrm{M}(1)$, site doublet; peaks 3 and $4=\mathrm{Fe}^{3+}$, M(2), site doublet.

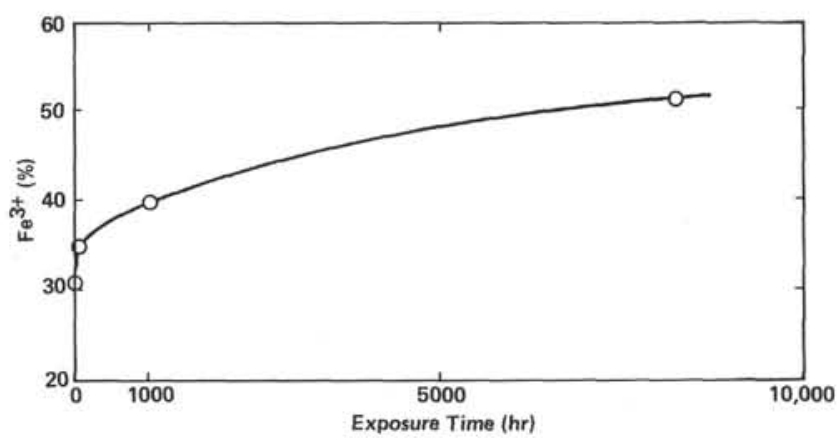

Figure 2. Increasing proportion of $\mathrm{Fe}^{3+}$ in saponite with increasing exposure to air.

The data in Table 2 indicate that negligible oxidation would have occurred during the 3 -hr interval required for sample recovery aboard Glomar Challenger. Thus, the $\mathrm{Fe}_{2} \mathrm{O}_{3} / \mathrm{FeO}$ ratio of the "unexposed" aliquot (0.46; $30 \% \mathrm{Fe}^{3+}$ ) may be taken as a good representation of the original, in situ composition of the saponite, while it remained in place about 350 meters below the seafloor. Utilizing this proportion of $\mathrm{Fe}^{3+}$ to supplement the electron-microprobe results in Table 4 modifies the cation abundances to yield a layer charge distribution much closer to the ideal (column 2). In the presence of $\mathrm{Fe}^{3+}$, the preservation of charge neutrality within octahedral layers requires a slightly low octahedral sum (VI). 


\section{SUMMARY AND DISCUSSION}

Our preliminary data suggest that:

1) A significant proportion of iron in deep-oceanfloor saponite can occur in the ferric oxidation state; however, the $\mathrm{Fe}_{2} \mathrm{O}_{3} / \mathrm{FeO}$ ratio remains at values significantly less than 1.0. As discussed by Andrews (1980), petrographic and geochemical observations indicate that saponite forms under relatively reducing conditions, at least in the region of sulfide stability ( $\mathrm{pH}$ slightly alkaline). We would suspect, as a general rule, that while $\mathrm{Fe}_{2} \mathrm{O}_{3} / \mathrm{FeO}$ ratios remain at less than 1.0 , they probably vary over a certain range in response to locally variable Eh conditions in the sub-sea-floor environment.

2) Both $\mathrm{Fe}^{2+}$ and $\mathrm{Fe}^{3+}$ in deep-ocean-floor saponite are octahedrally coordinated. There is no evidence to suggest the presence of $\mathrm{Fe}^{3+}$ in tetrahedral sites.

3) After recovery, $\mathrm{Fe}^{3+} / \mathrm{Fe}^{2+}$ ratios of saponite increase considerably because of oxidation under ambient laboratory or storage conditions. This oxidation does not induce any observable change in the physical appearance of the sample. Our data suggest that the proportion of $\mathrm{Fe}^{3+}$ can double in about a year. In this context, all published analyses of deep-ocean-floor saponites which include $\mathrm{Fe}_{2} \mathrm{O}_{3}$ and $\mathrm{FeO}$ data most likely represent oxidized rather than original, in situ compositions. It can be calculated that if $\mathrm{Fe}^{2+}$-bearing saponite occurs in modal abundances of 10 to $20 \%$, dispersed within the matrix of the rock, oxidation after sample recovery could significantly modify the whole-rock $\mathrm{Fe}_{2} \mathrm{O} /\left(\mathrm{FeO}+\mathrm{Fe}_{2} \mathrm{O}_{3}\right)$ ratio of the host basalt. For example, DSDP Leg 37 basalts containing 10 to $20 \%$ saponite (no other secondary phases present) yielded whole-rock $\mathrm{Fe}_{2} \mathrm{O}_{3} /\left(\mathrm{FeO}+\mathrm{Fe}_{2} \mathrm{O}_{3}\right)$ ratios of 0.3 to $0.4,18$ months after recovery (Andrews, 1979), compared to fresh basalt, which is usually in the range of 0.18 to 0.25 . Clearly this situation could lead to erroneous conclusions concerning the degree of oxidation in Layer 2 basalts, from the point of view of both igneous and secondary processes.

4) $\mathrm{The} \mathrm{Fe}^{3+}$ produced during oxidation of saponite remains octahedrally coordinated, at least to the composition limit of our experiment (a proportion of $51 \%$ $\mathrm{Fe}^{3+}$ ). This appears to be a close approach to equilibrium with respect to ambient air. Oxidation of $\mathrm{Fe}^{2+}$ to $\mathrm{Fe}^{3+}$ must result in a charge imbalance within the octahedral layers. Since our oxidation experiments were conducted in air, mechanisms for maintaining charge balance are limited to deprotonation of either structural hydroxyl groups or interlayer water molecules.

From detailed petrographic and mineralogical observations, Andrews (1980) has shown that saponite trans- forms to celadonite during low-temperature, oxidative diagenesis of Layer 2 basalt. However, free-energy considerations suggest nontronite (dioctahedral smectite) rather than celadonite (dioctahedral mica) as the most likely product of such a reaction. While nontronite is prolific as an authigenic constituent of deep-sea sediments and represents an important component of hydrothermal mounds, it is virtually absent as an in situ alteration product of Layer 2 basalts. Our ongoing studies involve a series of experiments, using the Leg 68 and 69 material, to investigate stability relationships among saponite, nontronite, and celadonite.

\section{ACKNOWLEDGMENTS}

We thank Margery Osborne for Mössbauer analysis of aliquot 4, Robert L. Barnett for microprobe analyses, and John Forth for thinsection and polished-section preparation. Special thanks to Jim Natland, who took care of sample selection and storage aboard Glomar Challenger. The manuscript benefited from critical reviews by G. M. Bancroft, of the University of Western Ontario, and C. Riddle of the Ontario Geological Survey. The initial part of this study was conducted at the Scripps Institution of Oceanography, Geological Research Division, La Jolla, California.

\section{REFERENCES}

Andrews, A. J., 1977. Low-temperature fluid alteration of oceanic layer 2 basalts, DSDP Leg 37. Can. J. Earth Sci., 14:911-926. 1979. On the effect of low temperature seawater-basalt interaction on the distribution of sulfur in oceanic crust, layer 2 . Earth Planet. Sci. Lett., 46:68-80.

, 1980. Saponite and celadonite in layer 2 basalts, DSDP Leg 37. Contr. Mineral. Petrol., 73:323-340.

Banks, H. H., 1972. Iron rich saponite: additional data on samples dredged from the Mid-Atlantic Ridge, $22^{\circ}$ N. Smithsonian Contr. Earth Sci., 9:39-42.

Bass, M. N., 1976. Secondary minerals in oceanic basalts with special reference to Leg 34, Deep Sea Drilling Project. In Yeats, R. S. Hart, S. R., et al., Init. Repts. DSDP, 34: Washington (U.S. Govt. Printing Office), 393-432.

Böhlke, J. K., Honnorez, J., and Honnorez-Guerstein, B. M., 1980. Alteration of basalts from Site 396B, DSDP: petrographic and mineralogic studies. Contr. Mineral. Petrol., 73:341-364.

Kohyama, N., Shimoda, S., and Sudo, T.; 1973. Iron-rich saponite (ferrous and ferric forms). Clays Clay Min., 21:229-237.

Rozenson, I., and Heller-Kallai, L., 1977. Mössbauer spectra of dioctahedral smectites. Clays Clay Min., 25:94-101.

1978. Reduction and oxidation of $\mathrm{Fe}^{3+}$ in dioctahedral smectites-III. Oxidation of octahedral iron in montmorillonite. Clays Clay Min., 26:88-92.

Seyfried, W. E. Jr., Shanks, W. C., and Dibble, W. E. Jr., 1978. Clay mineral formation in DSDP Leg 34 basalt. Earth Planet. Sci. Lett., 41:265-276.

Velde, B., 1972. Celadonite mica: solid solution and stability. Contr. Mineral. Petrol., 37:235-247.

Wise, W. S., and Eugster, H. P., 1964. Celadonite: synthesis, thermal stability and occurrences. Am. Mineral., 49:1031-1083. 